Sains Malaysiana 47(8)(2018): 1801-1810

http://dx.doi.org/10.17576/jsm-2018-4708-19

\title{
Attitude of Asians to Calcium and Vitamin D Rich Foods and Supplements:
}

\section{A Systematic Review}

(Sikap Orang Asia terhadap Makanan yang Kaya dengan Kalsium dan Vitamin D dan Penambahan Mutu Makanan)

\author{
CHIN Yi CHAN, NORAZlina MOHAMED, SOELAIMAN IMA-NIRWANA \& KOK-YONG CHIN*
}

\begin{abstract}
The prevalence of osteoporosis is increasing in Asian countries. Optimum calcium intake and vitamin D level are important to prevent osteoporosis. The attitude of the society towards calcium food sources and supplements, as well as sun exposure, influence their bone health practices. This review aimed to summarize the current literature on the attitude of Asians on calcium and vitamin D rich foods and supplements to understand the barriers among the Asians in achieving adequate calcium intake and vitamin D level. Studies showed that most Asians have a negative attitude towards calcium-rich foods, mainly dairy products due to lactose intolerance, aversion to the taste of dairy products or the absence of motivation. Although they took supplements to fill the gap in their diet, they were not aware of the daily recommended intake of calcium. Besides, the majority of them have a negative attitude towards sun exposure due to the fear of getting skin cancer or tanning. As a conclusion, most of Asians are still not aware of the importance of calcium and vitamin $D$ for their health and their negative attitude must be corrected to prevent the rise of osteoporosis.
\end{abstract}

Keywords: Barrier; bone; osteopenia; osteoporosis; perception; 25-hydroxyvitamin D

ABSTRAK

Kelaziman osteoporosis semakin meningkat di negara-negara Asia. Pengambilan kalsium dan vitamin D yang optimum adalah penting untuk mencegah osteoporosis. Sikap masyarakat terhadap sumber makanan kalsium dan suplemen, serta pendedahan kepada cahaya matahari, boleh mempengaruhi kesihatan tulang mereka. Ulasan ini bertujuan untuk merumuskan kajian terkini tentang sikap orang Asia terhadap suplemen dan makanan kaya kalsium serta vitamin D demi pengenalpastian sekatan mereka untuk mencapai tahap pengambilan kalsium dan vitamin D yang mencukupi. Kajian lepas telah menunjukkan kebanyakan orang Asia mempunyai sikap yang negatif terhadap makanan kaya kalsium, terutamanya produk tenusu, kerana mereka mengalami intolerans laktosa, tidak suka rasa produk tenusu atau kekurangan motivasi. Walaupun mereka mengambil suplemen untuk mengisi kekurangan dalam diet, mereka tidak mengetahui tahap pengambilan kalsium yang disyorkan. Di samping itu, kebanyakan mereka mempunyai sikap yang negatif terhadap pendedahan cahaya matahari kerana takut mendapat kanser kulit atau kulit gelap. Secara kesimpulannya, kebanyakan orang Asia masih tidak mengetahui kepentingan kalsium dan vitamin D untuk kesihatan mereka dan sikap ini harus diperbaiki untuk menghalang peningkatan osteoporosis.

Kata kunci: Osteopenia; osteoporosis; pandangan; sekatan; tulang; 25-hidroksivitamin D

\section{INTRODUCTION}

Calcium and vitamin D are nutrients essential for optimal bone health (Tai et al. 2015). They can be obtained from the diet, but vitamin D is mostly acquired through cutaneous synthesis when human skin is irradiated with ultraviolet B (280-320 nm). The recommended dietary intakes of calcium (1000 mg/day) and vitamin D (600 IU/per) to maintain bone health in human adults are well-established (Laird et al. 2010; Lehmann \& Meurer 2010; Lips \& Schoor 2011). The reference dietary intake of calcium and vitamin D purposed by Institute of Medicine are followed globally (Table 1) (Institute of Medicine 2011). However, calcium and vitamin D deficiency is still a worldwide epidemic. In the tropical Asian countries receiving abundant sunlight, the problem of vitamin D deficiency does exist. A study on 1139 Singaporean Malays, Chinese and Indians (624 males and 515 females) aged 40-80 years found that the prevalence of vitamin D insufficiency and deficiency were $28.4 \%$ and $47.8 \%$, respectively. Overall, Singaporean women had a higher prevalence of suboptimal $25(\mathrm{OH})$ D level compared to men (88.7\% vs. 65.7\%) (Man et al. 2017). Pregnant and lactating women have a higher requirement for vitamin $\mathrm{D}$ and calcium to provide for their babies and themselves (Dawodu \& Tsang 2012; Wagner et al. 2012). However, Wang et al. (2010) found that the prevalence of vitamin $\mathrm{D}$ and calcium insufficiency in pregnant women and neonates in Chengdu, China was high even when the mothers were compliant with prenatal vitamin supplementation (Wang et al. 2010). In the same study, calcium and vitamin D intake was uniformly low, although it was higher among urban women $(1010 \pm 450$ $\mathrm{mg} / \mathrm{d}, 237 \pm 169 \mathrm{IU} / \mathrm{d})$ than rural women $(320 \pm 210 \mathrm{mg} / \mathrm{d}$, 
$62 \pm 66 \mathrm{IU} / \mathrm{d}$ ) (Wang et al. 2010). Nutritional calcium deficiency is also prevalent in Southeast Asian countries, such as Indonesia (Green et al. 2008), Malaysia (Green et al. 2008) and Bangladesh (Islam et al. 2003).

The Asians face unique challenges in overcoming calcium and vitamin D deficiency. There is an increasing number of young adults in Southeast Asia countries working indoor due to rapid economic development. Meanwhile, the number of retired elderly having the leisure time to enjoy outdoor increases (Choi et al. 2011). This leads to a higher vitamin D level among the elderly compared to the younger generation as observed in Thailand (Chailurkit et al.2011), Malaysia (Chin et al. 2014) and Korea (Choi et al. 2011). Furthermore, Asians usually have skin type 4 or 5 (darker) compared with Caucasians (mostly skin type 2 or 3 ) (Webb $\&$ Engelsen 2006). Thus, Asians required a greater duration of sun exposure than Caucasians to synthesise comparable amount of vitamin D. Besides, dark skin pigmentation also put Asian adults at risk of vitamin D deficiency (Mitchell et al. 2012). The low vitamin D level among Asians is also associated with religious, lifestyle and nutritional factors. A study among Malaysian Muslim females found that they have low $25(\mathrm{OH}) \mathrm{D}$ levels due to fully covered attires (long sleeves, long skirts and veil), use of umbrella, avoidance the sunlight or working indoors (Moy 2011). Rahman et al. (2004) found that levels of 25(OH)D were significantly lower in the Malaysian Malay women (44.4 $\mathrm{nmol} / \mathrm{L})$ compared to the Malaysian Chinese women (68.8 $\mathrm{nmol} / \mathrm{L}$ ) (Rahman et al. 2004). Approximately $71 \%$ of the Malay women had vitamin D insufficiency (25-50 nmol/1) compared to $11 \%$ of the Chinese women. Lastly, children and adolescents in Asia have relatively low calcium intake in comparison to the Western counterparts (Gibson et al. 2007; Wu et al. 2007). This could be partly contributed by the non-dairy diets, poor dietary habits, inadequate information and knowledge about calcium-rich foods and poor calcium absorption from plant foods (Tupe \& Chiplonkar 2010).

It is important to understand the attitudes of the Asian population towards calcium and vitamin D to overcome the problems of inadequacy. It is recognized that awareness and a positive attitude towards health problems provide a powerful motivation for an individual to adopt healthy dietary behaviour (Brewer et al. 1999; Glasman \& Albarracin 2006). This review aimed to examine perception, attitude and beliefs of Asians on calcium- and vitamin D-rich foods, supplements and sun exposure.

\section{MATERIALS AND METHODS}

A literature search was performed from 30/8/2017 to 18/12/2017 with PubMed and Scopus using keywords '(perception OR attitude OR belief) AND (calcium OR vitamin D) AND (food OR supplement OR sun exposure)'. All original research articles published from the year 2000 onwards were considered to provide an up-to-date view of the attitudes of Asian populations on the subject matter. Our literature search identified 1371 records from Pubmed and 144 records from Scopus. After removing duplicated articles $(n=64)$, each title and abstract for

TABLE 1. Dietary Reference Intake for Calcium and Vitamin D

\begin{tabular}{|c|c|c|c|c|c|c|}
\hline \multirow[t]{2}{*}{ Life stage group } & \multicolumn{3}{|c|}{ Calcium } & \multicolumn{3}{|c|}{ Vitamin D } \\
\hline & $\begin{array}{l}\text { Estimated } \\
\text { average } \\
\text { requirement } \\
\text { (mg/day) }\end{array}$ & $\begin{array}{c}\text { Recommended } \\
\text { dietary allowance } \\
(\mathrm{mg} / \mathrm{day})\end{array}$ & $\begin{array}{l}\text { Upper level } \\
\text { intake } \\
(\mathrm{mg} / \text { day })\end{array}$ & $\begin{array}{l}\text { Estimated } \\
\text { average } \\
\text { requirement } \\
\text { (IU/day) }\end{array}$ & $\begin{array}{c}\text { Recommended } \\
\text { dietary } \\
\text { allowance } \\
\text { (IU/day) }\end{array}$ & $\begin{array}{l}\text { Upper level } \\
\text { intake } \\
\text { (IU/day) }\end{array}$ \\
\hline Infants 0 to 6 months & $*$ & $*$ & 1000 & $* *$ & $* *$ & 1000 \\
\hline Infants 6 to 12 months & $*$ & $*$ & 1500 & $* *$ & $* *$ & 1500 \\
\hline 1-3-year-old & 500 & 700 & 2500 & 400 & 600 & 2500 \\
\hline 4-8-year-old & 800 & 1000 & 2500 & 400 & 600 & 3000 \\
\hline 9-13-year-old & 1100 & 1300 & 3000 & 400 & 600 & 4000 \\
\hline 14-18-year-old & 1100 & 1300 & 3000 & 400 & 600 & \\
\hline 19-30-year-old & 800 & 1000 & 2500 & 400 & 600 & 4000 \\
\hline 31-50-year-old & 800 & 1000 & 2500 & 400 & 600 & 4000 \\
\hline 51-70-year-old males & 800 & 1000 & 2000 & 400 & 600 & 4000 \\
\hline 51-70-year-old females & 1000 & 1200 & 2000 & 400 & 600 & 4000 \\
\hline$>70$ years old & 1000 & 1200 & 2000 & 400 & 800 & 4000 \\
\hline 14-18 years old, pregnant/ lactating & 1100 & 1300 & 3000 & 400 & 600 & 4000 \\
\hline 19-50 years old, pregnant/lactating & 800 & 1000 & 2500 & 400 & 600 & 4000 \\
\hline
\end{tabular}

Sources: IOM 2011 
potential inclusion was screened. Only articles written in English or Mandarin were retrieved. Only original research articles with the main objective to study the perceptions, attitudes and beliefs on calcium and/or vitamin D foods and/or supplements and/or sun exposure among Asians were included in this review. If the article was potentially eligible for inclusion, the full text was examined. Two reviewers decided articles to be included in the review. Any discrepancies were resolved by discussion. Data extraction on authors (year), subjects' characteristics, study design, major findings were performed by the same person. A total of 15 articles fulfilled the criteria and provided sufficient information for data extraction and were included for this review (Figure 1).

\section{RESULTS}

\section{PERCEPTIONS, ATTITUDES AND BELIEFS OF ASIANS ON DIETARY CALCIUM}

Dairy products are a good source of dietary calcium but lactose intolerance is prevalent among the Asians (Qiao et al.2011; Saha et al.2016). A study by Asmawi et al. (2006) found that $88 \%$ Malays, 91\% Chinese and $83 \%$ Indians in Malaysia were hypolactasic. The attitude of Chinese urban population ( $n=1714$, from 18 years old to above 65 years old, $34 \%$ men, $66 \%$ women) on dairy products has been investigated by Zhao et al. (2017). They found that $42.7 \%$ subjects had a self-perceived insufficient intake of dairy products (Zhao et al. 2017). Only $15.2 \%$ of the subjects mentioned that they experienced lactose intolerance symptoms after consuming dairy products in this study (Zhao et al. 2017). This prevalence was much lower than the estimated prevalence of lactose intolerance previously reported in China (92.3\% in Han Chinese) (Wang et al. 1984). Among those experiencing the symptoms, $29.5 \%$ were unsure of the reasons, $21.7 \%$ considered the cause was lactose intolerance, while $48 \%$ speculated other gastrointestinal conditions (Zhao et al. 2017).

This reason, along with the lack information on the recommended daily calcium intake might prevent Asians from obtaining sufficient calcium. A cross-sectional survey of 1475 Thai adults aged 20 years or above expressed a positive attitude towards the essential role of calcium in health and the need to fulfil the intake requirement (Sriring et al. 2014). However, only $10.9 \%$ fulfilled the recommended calcium intake level ( $800 \mathrm{mg}$ /day) (Sriring et al. 2014). This might be attributed to the fact that only $4.6 \%$ of them were aware of this value in the survey (Sriring et al.2014). Despite using a multistage randomized sampling method, this study focused on the north-eastern part of Thailand, which might not be presentative of the whole country.

With respect to Asians living in the Western countries, Reicks et al. (2011) reported that among 661 parents recruited in nine states in the USA, being Asian and having an Asian spouse contributed to lower calcium intake. Another similar study also indicated that Asian parents were least likely to be a dedicated milk drinker and provider (Reicks et al. 2012). A qualitative survey conducted among adolescent girls from Asian, Hispanic or Caucasian ethnicity showed that more Asian subjects disliked the taste of milk compared to other ethnicities (Auld et al. 2002). However, they could accept other dairy food products, such as cheese, pizza and ice-cream (Auld et al. 2002). They also thought that there was a lack of expectation within their families to drink milk and milk was not compatible with Asian food (Auld et al. 2002). Across ethnicities, the subjects associated milk with musculoskeletal benefits but thought that it was more important to the boys (Auld et al. 2002). Overall, the attitude of Asian adolescent girls towards milk was less negative compared to the Hispanics

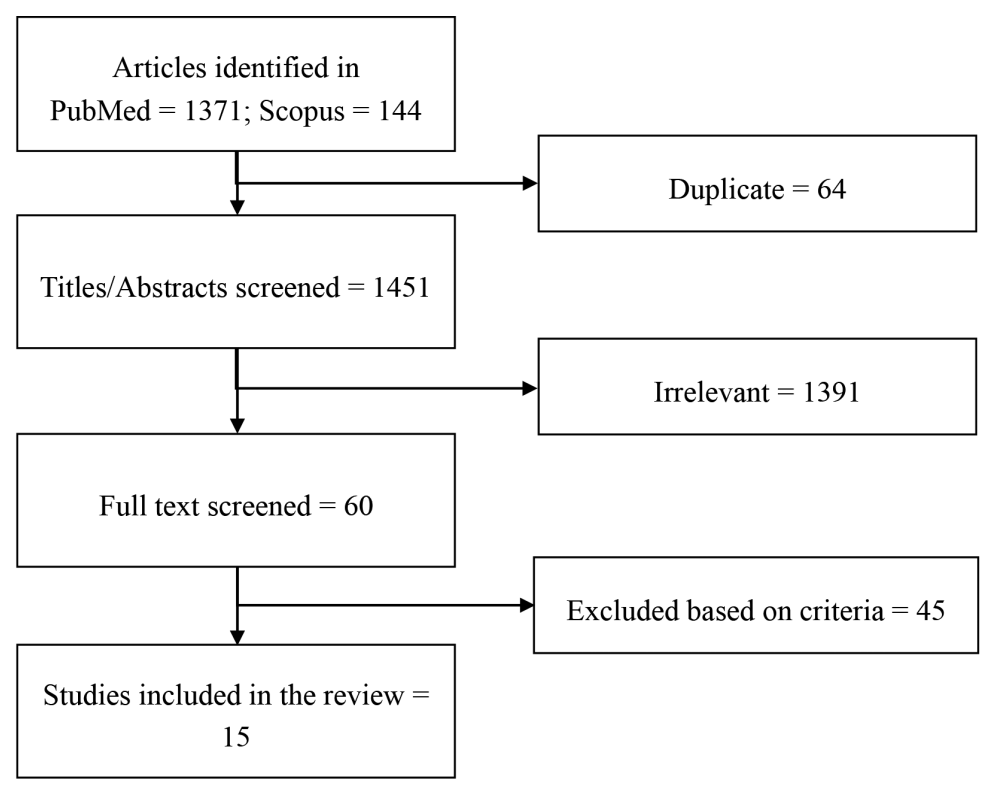

FIGURE 1. Flow diagram of the stepwise selection of relevant studies 
but less positive compared to the Caucasians (Auld et al. 2002). The readers should note that these studies were performed in conveniently sampled subjects (Auld et al. 2002; Reicks et al. 2011), therefore, generalization of the results should be done with cautions.

A summary of the literature on the attitudes of Asians on calcium-rich food is listed in Table 2.

\section{PERCEPTIONS, ATTITUDES AND BELIEFS OF ASIANS ON CALCIUM AND VITAMIN D SUPPLEMENTS}

Calcium supplements are recommended for individuals who cannot achieve daily recommended calcium intake. Only one study on the attitudes of Asians on calcium supplementation was found. A multinational survey by Chan et al. (2010) studied the attitudes of physicians $(n=237)$ and patients $(n=1463)$ on calcium supplementation. The proportion of physicians with positive attitudes on calcium in descending order was the Philippines $(80 \%)$ $>$ Korea $(50 \%)>$ Singapore $(38 \%)>$ Taiwan $(30 \%)>$ Malaysia (27\%). Meanwhile, the proportion of patients with positive attitudes on calcium in descending order was the Philippines $(90 \%)>$ Korea $(70 \%)>$ Malaysia $(69 \%)>$ Taiwan $(58 \%)>$ Singapore $(55 \%)$ (Chan et al. 2010). Similar trends in attitudes were found for vitamin D supplement, whereby the Philippine physicians (72\%) and patients $(73 \%)$ had the most positive attitudes compared to the other countries. The positive attitude on calcium and vitamin D supplements in the Philippines was contributed by frequent discussions about supplementations between the physicians and the patients, denoted by $81 \%$ of the respondents. In other countries studied, more than half of the patients had no or infrequent discussion with the doctors about supplementation (Chan et al. 2010). Despite being a rare multinational study in the Asian region and the numbers of the physicians and patients recruited were relatively large, the representation of the samples might be hampered by the non-randomized sampling method.

Vitamin D deficiency was a serious problem among the neonates ( $\mathrm{Wu} 2014$ ). Without proper immediate intervention, it could lead to rickets and fracture. With regards to this issue, the attitude of Turkish paediatricians on vitamin D supplementations in their clinical practice was examined (Karabulut et al. 2016). The results showed that only $8.7 \%$ subjects would recommend beginning vitamin D prophylaxis soon after birth probably due to the misconception that maternal transfer of vitamin D could protect against deficiency for the first three weeks of life (Karabulut et al. 2016). Besides, 19.9\% of the subjects would stop vitamin D supplementation immediately in infants with small anterior fontanelle due to the false belief that it would delay its closure (Karabulut et al. 2016). A small percentage of subjects would recommend vitamin D in babies with delayed tooth eruption $(7.8 \%$, daily dose) and walking (2.4\%, 300 IU every two months) (Karabulut et al. 2016). These indications could lead to intoxication because vitamin D at $300 \mathrm{IU}$ is available over the counter in Turkey (Karabulut et al. 2016). It should be noted that the response rate of this survey was quite low (167/1800) and the aspects of vitamin D supplementation studied were limited.

A summary of the literature on the attitude of Asians on calcium supplement is listed in Table 3.

TABLE 2. Perceptions, attitudes and beliefs of Asians on dietary calcium

\begin{tabular}{|c|c|c|c|c|}
\hline Studies & Primary objective & Populations & Study design & Findings \\
\hline Zhao et al. (2017) & $\begin{array}{l}\text { To determine the } \\
\text { knowledge, attitude } \\
\text { and practice of dairy } \\
\text { products in Chinese } \\
\text { urban population }\end{array}$ & $\begin{array}{l}1714 \text { subjects aged } \\
\text { from } 18-65 \text { years and } \\
\text { above from first-tiers } \\
\text { and non-first tiers } \\
\text { cities of China }\end{array}$ & $\begin{array}{l}\text { Cross-sectional study using } \\
\text { the Semi-Quantitative Food } \\
\text { Frequency Questionnaire } \\
\text { (semi-FFQ) }\end{array}$ & $\begin{array}{l}42.7 \% \text { self-perceived insufficient } \\
\text { dairy intake } \\
15.2 \% \text { experiencing lactose } \\
\text { intolerance symptoms but only } \\
21.7 \% \text { thought it was related to } \\
\text { lactose intolerance }\end{array}$ \\
\hline Sriring et al. (2014) & $\begin{array}{l}\text { To determine the } \\
\text { knowledge and attitudes } \\
\text { of Thai adults towards } \\
\text { calcium and predictors } \\
\text { of calcium consumption }\end{array}$ & $\begin{array}{l}1475 \text { Thai adults } \\
\text { from } 20 \text { provinces } \\
\text { in the northeastern } \\
\text { region of Thailand }\end{array}$ & $\begin{array}{l}\text { Cross-sectional study } \\
\text { using structured interview } \\
\text { questionnaire }\end{array}$ & $\begin{array}{l}\text { Positive attitude: role of calcium } \\
\text { in health and the need for } \\
\text { regular intake } \\
\text { Only } 4.6 \% \text { could specify the } \\
\text { value of the daily requirement } \\
\text { for calcium }\end{array}$ \\
\hline Reicks et al.(2011) & $\begin{array}{l}\text { To determine the } \\
\text { influence of parental } \\
\text { perception on calcium- } \\
\text { rich food on calcium } \\
\text { intake on adolescence }\end{array}$ & $\begin{array}{l}\text { Non-Hispanic white, } \\
\text { Hispanic, and Asian } \\
(n=661) \text { parents from } \\
\text { nine states }\end{array}$ & $\begin{array}{l}\text { Cross-sectional study using } \\
14 \text { scales questionnaire } \\
\& \text { food frequency } \\
\text { questionnaire }\end{array}$ & $\begin{array}{l}\text { Having an Asian spouse or } \\
\text { being Asian was associated with } \\
\text { reduced calcium intake }\end{array}$ \\
\hline Auld et al. (2002) & $\begin{array}{l}\text { To determine factors } \\
\text { influencing milk } \\
\text { consumption among } \\
\text { adolescent girls }\end{array}$ & $\begin{array}{l}\text { Female adolescent } \\
\text { (11 to } 12 \text { or } 16 \text { to } 17 \\
\text { years) (Ethnic: Asian, } \\
\text { Hispanic, white) }\end{array}$ & $\begin{array}{l}\text { Cross-sectional qualitative } \\
\text { study using focus group } \\
\text { discussion }\end{array}$ & $\begin{array}{l}\text { Most Asian subjects had a } \\
\text { negative attitude to milk due to } \\
\text { absence of expectation within } \\
\text { Asian families for drinking milk }\end{array}$ \\
\hline
\end{tabular}




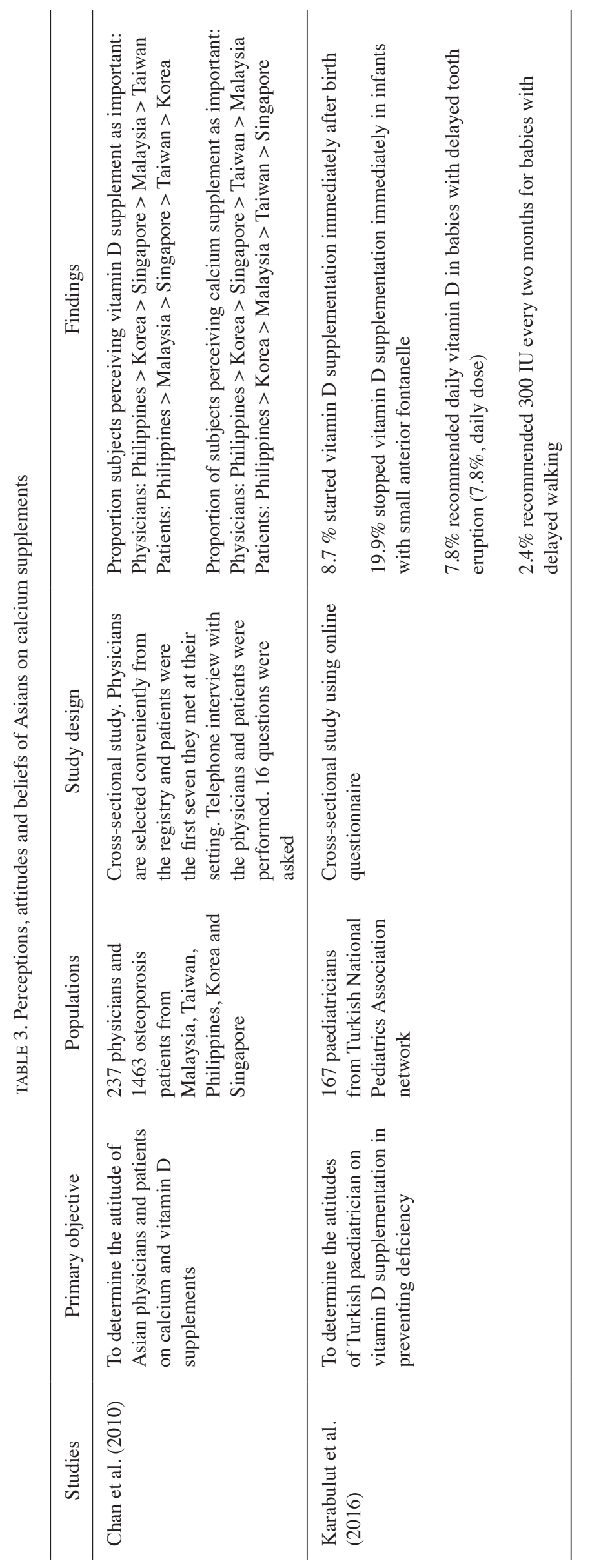


PERCEPTIONS, ATTITUDES AND BELIEFS OF ASIANS ON OBTAINING VITAMIN D VIA SUN EXPOSURE

The tendency to avoid sunlight due to aesthetic reasons is prevalent among the Asian populations. A study by Kung and Lee (2006) in Hong Kong population ( $n=547)$ showed that despite having good awareness about vitamin $\mathrm{D}$, middle-aged women tended to have a negative attitude towards sunlight compared with elderly women. Many of them took measures to avoid sun exposure whenever possible, these might be due to the current cultural trend to maintain a paler skin (Kung \& Lee 2006). The awareness of the harmful effects of sunlight (for example, skin ageing and cancer) exerted a greater influence on sun exposure behaviour among middle-aged women than the knowledge about the benefits of sunlight (Kung \& Lee 2006). Another study among medical university students in Northeast China $(n=385)$ found a significant gender disparity in their attitude towards tanning. Men showed a positive attitude towards tanning (looked healthier and attractive), but women showed a negative attitude (looked older) (Gao et al. 2014). Similarly, a study among medical university students $(n=515)$ in Nanjing, China found out that the main reason for preventing sun exposure was to avoid tanning (males $43.2 \%$ and females $75.0 \%$ ) (Zhou et al. 2016). The lack of sun exposure was further validated in the use of sun protection, especially in female students (30.2\%) (Zhou et al. 2016). This finding is similar to another study among students in an Indian university, whereby $64.2 \%$ respondents did not like going in the sun (women $>$ men) (Arora et al. 2016). Half of them (49.7\%) thought that sun exposure was harmful and $43 \%$ would always use a sunscreen when going out (women $>$ men) (Arora et al. 2016). Besides, $60 \%$ of the subjects also self-perceived to be sufficient in vitamin D (men>women) (Arora et al. 2016). The subjects of this study were from the same department of a single university and with biotechnology background. Hence, the results might not be generalized to other young adult populations in India.

The attitude of the populations in Middle-east may be different from the rest of Asia. Aljefree et al. (2017) performed a qualitative study to assess the attitude to vitamin D in Saudi Arabia. The interviewed subjects showed that they were only willing to expose themselves to sunlight in the morning or late evening, and limit the exposure to face and hands. They also thought that hot climate, the design of modern house (close, high-rise, without balcony), limited public recreational areas for outdoor activities and certain physical conditions, physical inactivity and religious practices inhibited them to obtain sufficient sunlight. In another study which was also conducted in Abu Dhabi, Saudi Arabia among a limited number of conveniently sampled young women $(n=193)$ with an average age of 25 years, 'being in sunlight was bad for health' was the strongest predictors of sun avoidance (Thomas et al. 2010). In contrast, Mousavi et al. (2011) found out that most citizens of Shahrak-E-Gharb $(n=400$; conveniently sampled), an area in northwest Tehran have a positive attitude about sun exposure. Only $15 \%$ of them were concerned about skin cancer due to sun exposure and $61.8 \%$ of them believed skin cancer could be prevented by sun protection. $78.5 \%$ of them thought tanning made them more charming (Mousavi et al. 2011).

The attitude of Asian immigrants in New Zealand had been studied by Von Hurst et al. (2010). The respondents were 140 South Asian women living in Auckland aged 20 years or above. Most subjects (69\%) never sunbathed and $24 \%$ wore a sunscreen when going out (Von Hurst et al. 2010). The reasons they avoided sunlight included public health messages (30\%), avoid tanning (19\%) and health reason (15\%) (Von Hurst et al. 2010). On improving their sunlight exposure, $29 \%$ subjects indicated that would never want to spend more time under the sun, $49 \%$ would increase exposure if skin cancer was not a concern, $24 \%$ would increase if they had more time and $9 \%$ would if they had more privacy (Von Hurst et al. 2010). This study only involved South Asian women conveniently sampled from Auckland, therefore, the results should not be extrapolated to other Asian immigrants.

Asians with health conditions might be more incline to improve their health status through sunlight exposure. In a case-control study among patients with coronary heart disease, the cases $(n=130)$ had a more positive attitude towards sun exposure, evidenced by higher willingness to expose themselves to sunlight, not avoiding sunlight, higher concern about their vitamin D level and not using parasol to shade themselves compared to control $(n=195)$ (Aljefree et al. 2017). However, their positive attitudes were not associated with vitamin D level (Aljefree et al. 2017). Only patients with a coronary heart disease were studied so far, thus we did not know whether patients with other conditions would share the same attitude on sun exposure.

A summary of the literature on the attitudes of Asians on vitamin D supplement is listed in Table 4.

\section{PERSPECTIVES}

The attitude of Asians towards calcium-rich food is influenced by a myriad of biological and cultural factors. Public education plays an important role in eliminating ignorance and biases towards calcium-rich foods. Given the importance of calcium for healthy development and growth, individuals with lactose intolerance should be made aware of lactose free-dairy products, which can help them to obtain the complete nutritional value of the milk (Beto 2015). Besides, parents are equally important in ensuring family members have access to calcium-rich foods. Edlefsen et al. (2008) suggested that parents should always make calcium and vitamin D-rich foods or beverages available at home for their children. Furthermore, parents should take a proactive role in emphasizing the health benefits of maintaining a calcium and vitamin D-rich diet to their children at different stages of their development (Edlefsen et al. 2008).

Populations at the highest risk for dietary calcium deficiency, such as women (amenorrhoeic, athlete triad, 


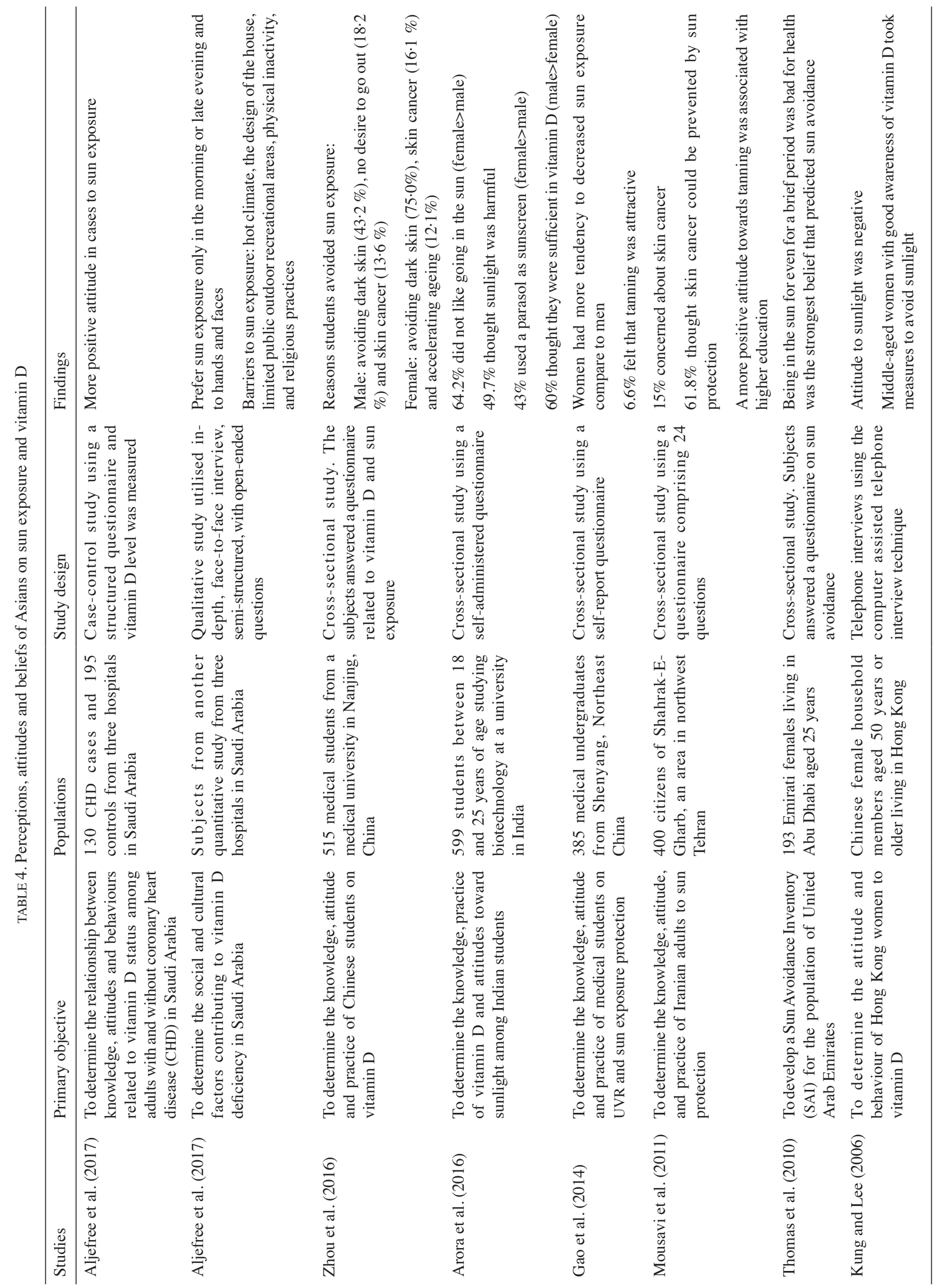


postmenopausal), individuals with milk allergy or lactose intolerance, adolescents and elderly (National Institute of Health Osteoporosis and Related Bone Diseases National Resource Centre 2015), should seek nutritional and medical consultation in starting calcium supplementation. This is important because either under or over-supplementation will not be beneficial to health. In addition, under-supplementation is a waste of resources and over-supplementation could induce other medical conditions. The physicians, especially those involved in primary care, should communicate with their patients on the benefits and appropriate use of calcium and vitamin D supplements.

With regards to vitamin D and sunlight, the attitude of Asians is influenced by cultural and religious factors. Ambient ultraviolet radiation (UVR) distribution and temperature are a major concern in the population who avoided sun exposure due to aesthetic reasons and fear of skin cancer. Thus, it is recommended that they performed outdoor activities in the early morning or evening to prevent skin damage from UVR (Cheng et al. 2010). Public health message should also strike a balance between benefits and risks for sun exposure (Thomas et al. 2010). This is to ensure the public does not shun from sunlight totally. For those susceptible to vitamin D deficiency due to religious clothing, older adults, individuals with a dark skin tone or obesity, supplementation may be required.

Lastly, the updated literature on the attitudes of Asian populations is limited. Most studies were performed among the Chinese and Middle-eastern populations and fewer for other ethnicities. More intensive studies should be performed to understand the barriers among the Asians to achieve adequate calcium intake and vitamin D level. One of the concerns is that the elderly population in Asia is expanding exponentially. Concurrently, the prevalence of age-related diseases, like osteoporosis, is also increasing. It is estimated that the percentage of global hip fracture in Asia will increase from $24 \%$ in 1990 to $45 \%$ in 2050 (Gullberg et al. 1997). Slowing down the increase through nutritional strategies, for instance, ensuring adequate calcium and vitamin D intake, is essential in reducing the burden of diseases like osteoporosis.

\section{CONCLUSION}

Asians have certain negative attitudes towards calciumrich foods, especially dairy products, due to the prevalence of lactose intolerance, absence of family motivation and aversion driven by taste and misconceptions. Despite their willingness to take supplementation, they are not equipped with the knowledge of recommended daily calcium intake, often resulting in under-supplementation. Similarly, they have a negative attitude towards sun exposure, mostly driven by aesthetic reasons and fear of skin cancer. These negative attitudes should be corrected through public health education to ensure sufficient calcium intake and vitamin $\mathrm{D}$ level in preventing health problems.

\section{ACKNOWLEDGEMENTS}

We thank Universiti Kebangsaan Malaysia for supporting the study with grants GUP-2016-060 and AP-2017-009/1.

\section{REFERENCES}

Aljefree, N., Lee, P. \& Ahmed, F. 2017. Exploring knowledge and attitudes about vitamin D among adults in Saudi Arabia. A Qualitative Study. Healthcare (Basel) 5(4): E76.

Aljefree, N.M., Lee, P. \& Ahmed, F. 2017. Knowledge and attitudes about vitamin $\mathrm{D}$, and behaviors related to vitamin $D$ in adults with and without coronary heart disease in Saudi Arabia. BioMed. Central Public Health 17(1): 266.

Arora, H., Dixit, V. \& Srivastava, N. 2016. Evaluation of knowledge, practices of vitamin D and attitude toward sunlight among indian students. Asian Journal of Pharmaceutical and Clinical Research 9(1): 284-289.

Asmawi, M.Z., Seppo, L., Vapaatalo, H. \& Korpela, R. 2006. Hypolactasia \& lactose intolerance among three ethnic groups in Malaysia. Indian Journal of Medical Research 124(6): 697-704.

Auld, G., Boushey, C.J., Bock, M.A., Bruhn, C., Gabel, K., Gustafson, D., Holmes, B., Misner, S., Novotny, R., Peck, L., Pelican, S., Pond-Smith, D. \& Read, M. 2002. Perspectives on intake of calcium-rich foods among asian, hispanic, and white preadolescent and adolescent females. Journal of Nutrition Education and Behaviour 34(5): 242-251.

Anon, 2015. Calcium and Vitamin D Important at Every Age. National Institute of Health Osteoporosis and Related Bone Diseases National Resource Centre.

Beto, J.A. 2015. The role of calcium in human aging. Clinical Nutrition Research 4(1): 1-8.

Brewer, J.L., Blake, A.J., Rankin, S.A. \& Douglass, L.W. 1999. Theory of reasoned action predicts milk consumption in women. Journal of the American Dietetics Association 99(1): 39-44.

Chailurkit,L.O.,Aekplakorn,W.\& Ongphiphadhanakul, B. 2011. Regional variation and determinants of vitamin D status in sunshine-abundant Thailand. Biomed. Central Public Health 11: 853 .

Chan, S.P., Scott, B.B. \& Sen, S.S. 2010. An asian viewpoint on the use of vitamin D and calcium in osteoporosis treatment: Physician and patient attitudes and beliefs. BioMed. Central Musculoskeletal Disorder 11: 248.

Cheng, C.E., Irwin, B., Mauriello, D., Hemminger, L., Pappert, A. \& Kimball, A.B. 2010. Health disparities among different ethnic and racial middle and high school students in sun exposure beliefs and knowledge. The Journal of Adolescene Health 47(1): 106-109.

Chin, K.Y., Ima-Nirwana, S., Ibrahim, S., Mohamed, I.N. \& Wan Ngah, W.Z. 2014. Vitamin D status in Malaysian men and its associated factors. Nutrients 6(12): 5419-5433.

Choi, H.S., Oh, H.J., Choi, H., Choi, W.H., Kim, J.G., Kim, K.M., Kim, K.J., Rhee, Y. \& Lim, S.K. 2011. Vitamin D insufficiency in Korea - a greater threat to younger generation: the Korea National Health and Nutrition Examination Survey (KNHANES) 2008. The Journal of Clinical Endocrinology and Metabolism 96(3): 643-651.

Dawodu, A. \& Tsang, R.C. 2012. Maternal vitamin D status: Effect on milk vitamin D content and vitamin D status of breastfeeding infants. Advance in Nutrition 3(3): 353-361.

Edlefsen, M., Reicks, M., Goldberg, D., Auld, G., Bock, M.A., Boushey, C.J., Bruhn, C., Cluskey, M., Misner, S., Olson, 
B., Wang, C. \& Zaghloul, S. 2008. Strategies of asian, hispanic, and non-hispanic white parents to influence young adolescents" intake of calcium-rich foods, 2004 and 2005. Preventing Chronic Disease 5(4): A119-A119.

Gao, Q., Liu, G. \& Liu, Y. 2014. Knowledge, attitude and practice regarding solar ultraviolet exposure among medical university students in northeast China. Journal of Photochemistry and Photobiology B 140: 14-19.

Gibson, R.S., Manger, M.S., Krittaphol, W., Pongcharoen, T., Gowachirapant, S., Bailey, K.B. \& Winichagoon, P. 2007. Does zinc deficiency play a role in stunting among primary school children in NE Thailand?. The British Journal of Nutrition 97(1): 167-175.

Glasman, L.R. \& Albarracin, D. 2006. Forming attitudes that predict future behavior: A meta-analysis of the attitudebehavior relation. Psychological Bulletin 132(5): 778-822.

Green, T.J., Skeaff, C.M., Rockell, J.E., Venn, B .J., Lambert, A., Todd, J., Khor, G.L., Loh, S.P., Muslimatun, S., Agustina, R. \& Whiting, S.J. 2008. Vitamin D status and its association with parathyroid hormone concentrations in women of childbearing age living in Jakarta and Kuala Lumpur. European Journal of Clinical Nutrition 62(3): 373-378.

Gullberg, B., Johnell, O. \& Kanis, J.A. 1997. World-wide projections for hip fracture. Osteoporosis International 7(5): 407-413.

Institute of Medicine. 2011. Dietary Reference Intakes for Calcium and Vitamin D. Washington: National Academies Press.

Islam, M.Z., Lamberg-Allardt, C., Karkkainen, M. \& Ali, S.M. 2003. Dietary calcium intake in premenopausal bangladeshi women: Do socio-economic or physiological factors play a role? European Journal of Clinical Nutrition 57(5): 674-680.

Kung, A.W. \& Lee, K.K. 2006. Knowledge of vitamin D and perceptions and attitudes toward sunlight among chinese middle-aged and elderly women: A population survey in Hong Kong. BioMed. Central Public Health 6: 226.

Karabulut, G.S., Hatun, S., Bideci, A. \& Hasanoglu, E. 2016. Attitudes of pediatricians regarding prevention and treatment of vitamin D deficiency. Journal of Clinical Research in Pediatric Endocrinology 8(3): 368-371.

Laird, E., Ward, M., McSorley, E., Strain, J.J. \& Wallace, J. 2010. Vitamin D and bone health: Potential mechanisms. Nutrients 2(7): 693-724.

Lehmann, B. \& Meurer, M. 2010. Vitamin D metabolism. Dermatologic Therapy 23(1): 2-12.

Lips, P. \& Schoor, N.M.V. 2011. The effect of vitamin D on bone and osteoporosis. Best Practice Research: Clinical Endocrinology and Metabolism 25(4): 585-591.

Man, R.E., Li, L.J., Cheng, C.Y., Wong, T.Y., Lamoureux, E. \& Sabanayagam, C. 2017. Prevalence and determinants of suboptimal vitamin $\mathrm{D}$ levels in a multiethnic asian population. Nutrients 9(3): 313 .

Mitchell, D.M., Henao, M.P., Finkelstein, J.S. \& Burnett-Bowie, S.A. 2012. Prevalence and predictors of vitamin D deficiency in healthy adults. Endocrinology Practice 18(6): 914-923.

Mousavi, F., Golestan, B., Vaseie, M., Vaseie, L. \& KhajehKazemi, R. 2011. Knowledge, attitude, and practice of adults to the protective actions against sun in northwest Tehran, Iran. Archives of Iranian Medicine 14(2): 126-131.

Moy,F.M. 2011. Vitamin D status and its associated factors of free living malay adults in a tropical country, Malaysia. Journal of Photochemistry and Photobiology B 104(3): 444-448.
Qiao, R., Huang, C., Du, H.,Zeng, G.,Li, L. \& Ye, S. 2011. Milk consumption and lactose intolerance in adults. Biomedical and Environmental Science 24(5): 512-517.

Rahman, S.A., Chee, W.S., Yassin, Z.\& Chan, S.P. 2004 . Vitamin D status among postmenopausal malaysian women. Asia Pacific Journal of Clinical Nutrition 13(3): 255-260.

Reicks, M., Ballejos, M.E., Goodell, L.S., Gunther, C., Richards, R., Wong, S.S., Auld, G., Boushey, C.J., Bruhn, C., Cluskey, M., Misner, S., Olson, B. \& Zaghloul, S. 2011. Individual and family correlates of calcium-rich food intake among parents of early adolescent children. Journal of American Dietetics Association 111(3): 376-384.

Reicks, M., Degeneffe, D., Ghosh, K., Bruhn, C., Goodell, L.S., Gunther, C., Auld, G., Ballejos, M., Boushey, C., Cluskey, M., Misner, S., Olson, B., Wong, S. \& Zaghloul, S. 2012. Parent calcium-rich-food practices/perceptions are associated with calcium intake among parents and their early adolescent children. Public Health Nutrition 15(2): 331-340.

Saha, M., Shil, B.C., Saha, S.K., Chowdhury, M., Perveen, I., Banik, R. \& Rahman, M.H. 2016. Prevalence and symptom correlation of lactose intolerance in the north east Part of Bangladesh. Mymensingh Medical Journal 25(1): 72-78.

Sriring, P., Krass, I. \& Kanjanarach, T. 2014. Calcium consumption for osteoporosis prevention: Knowledge, attitudes and behavior in the northeastern region, Thailand. Journal of Medical Association of Thailand 97(2): 232-240.

Tai, V., Leung, W., Grey, A., Reid, I.R. \& Bolland, M.J. 2015. Calcium intake and bone mineral density: Systematic review and meta-analysis. British Medical Journal 351: h4183.

Thomas, J., Alanouti, F., Campbell, C. \& Ameri, S.A. 2010. Exploring sun avoidant attitudes and behaviors in the United Arab Emirates. Social Behavior and Personality 38(8): 1111-1118.

Tupe, R.\& Chiplonkar, S.A. 2010. Diet patterns of lactovegetarian adolescent girls: Need for devising recipes with high zinc bioavailability. Nutrition 26(4): 390-398.

Von Hurst, P.R., Stonehouse, W. \& Coad, J. 2010. Vitamin D status and attitudes towards sun exposure in south asian women living in Auckland, New Zealand. Public Health Nutrition 13(4): 531-536.

Wagner, C.L., Taylor, S.N., Johnson, D.D. \& Hollis, B.W. 2012. The role of vitamin D in pregnancy and lactation: Emerging concepts. Womens Health (Lond) 8(3): 323-340.

Wang, J., Yang, F., Mao, M., Liu, D.H., Yang, H.M. \& Yang, S.F. 2010. High prevalence of vitamin D and calcium deficiency among pregnant women and their newborns in Chengdu, China. World Journal of Pediatric 6(3): 265-267.

Wang, Y.G., Yan, Y.S., Xu, J.J., Du, R.F., Flatz, S.D., Kuhnau, W. \& Flatz, G. 1984. Prevalence of primary adult lactose malabsorption in three populations of northern China. Human Genetics 67(1): 103-106.

Webb, A.R. \& Engelsen, O. 2006. Calculated ultraviolet exposure levels for a healthy vitamin D status. Photochemistry and Photobiology 82(6): 1697-1703.

Wu, S.J., Pan, W.H., Yeh, N.H. \& Chang, HY. 2007. Dietary nutrient intake and major food sources: The nutrition and health survey of Taiwan elementary school children 20012002. Asia Pacific Journal of Clinical Nutrition 16 (Suppl 2): $518-533$

Wu, Z. 2014. Vitamin D supplementation in neonates. BMJ Quality Improvement Reports 3(1): u203171.w201436.

Zhao, A., Szeto, I.M.Y., Wang, Y., Li, C., Pan, M., Li, T., Wang, P. \& Zhang, Y. 2017. Knowledge, attitude, and practice (KAP) 
of dairy products in chinese urban population and the effects on dairy intake quality. Nutrients 9(7): 668.

Zhou, M., Zhuang, W., Yuan, Y., Li, Z. \& Cai, Y. 2016. Investigation on vitamin $\mathrm{D}$ knowledge, attitude and practice of university students in Nanjing, China. Public Health Nutrition 19(1): 78-82.

Department of Pharmacology

Faculty of Medicine

Universiti Kebangsaan Malaysia

Jalan Yaacob Latif, Bandar Tun Razak

56000 Cheras, Kuala Lumpur, Federal Territory

Malaysia
*Corresponding author; email: chinkokyong@ppukm.ukm. edu.my

Received: 11 January 2018

Accepted: 19 April 2018 